\title{
Composition Characteristics of Dissolved Organic Matter at the Vegetation-Soil Interface Under the Influence of Mining Disturbances
}

\author{
Li Zhang',2*, Qingxuan Sun ${ }^{2}$, Kai Zhang ${ }^{1}$, Zhiguo Cao ${ }^{1}$, Haichao Zhao ${ }^{3}$, \\ Haixiang Zhao ${ }^{3}$, Jiongqi Wang ${ }^{3}$, Pan $\mathbf{L i}^{3}$ \\ ${ }^{1}$ China Energy Investment Corporation State, Key Laboratory of Water Resource Protection \\ and Utilization in Coal Mining, Beijing 102211, China \\ ${ }^{2}$ Beijing University of Technology, National Engineering Laboratory for Advanced Municipal \\ Wastewater Treatment and Reuse Technology, Beijing 100124, China \\ ${ }^{3}$ Hebei North University, Hebei Provincial Key Lab of Quality and Safety Analysis of Agricultural Products,
} Zhangjiakou 075000, China

Received: 18 February 2021

Accepted: 18 May 2021

\begin{abstract}
The contradiction between coal mining and environmental protection is becoming increasingly acute. In this study, we analyzed the distribution of carbon content and the components and structural characteristics of dissolved organic matter (DOM) at the vegetation-soil interface of mine dumps and explored the potential environmental mechanism of the recovery process. The study results indicated that the DOM content at the vegetation-soil interface was $320.82-403.81 \mathrm{mg} / \mathrm{kg}$, decreasing in the first 1-3 years and then increasing between years 5 and 7 . With increasing time from the creation of the dump, hydrophilic and microbial materials at the vegetation-soil interface turned, most of which were integrated into humic-like substances and protein-like substances. Moreover, the adsorption capacity of DOM to organic pollutants and metal ions decreased, increasing the potential risk of vegetation-soil interface pollution. However, the content of newly formed humic acid in DOM gradually enhanced, improving the fertility of the vegetation-soil interface. Vegetation types and $\mathrm{pH}$ were the key factors affecting the spatial distribution of carbon content and the composition characteristics of DOM at the vegetation-soil interface. Thus, studying the composition characteristics of DOM in the vegetation-soil interface can help establish a relationship with the soil quality and offer novel ideas for the management of the mining dumps.
\end{abstract}

Keywords: mining dump, vegetation-soil interface, dissolved organic matter, composition characteristics, spectral characterization

*e-mail: zhangli19821115a@163.com 


\section{Introduction}

Coal is one of the most important energy sources in China, and plays an important role in the development of the national economy. In open-pit coal mining, the original surface vegetation, surface rock, and soil are stripped, whereas the deep soil layer is removed to form a dump. Such changes in the soil structure, physical and chemical properties, and vegetation community cause land degradation and fertility decline, which in turn, affect the mineralization and migration of soil organic carbon [1-2]. Vegetation restoration is a key to the ecological restoration of mine dumps. Litter and root exudates help accelerate soil fertility restoration, prevent soil erosion, and improve soil carbon storage [3-4]. Soil carbon content and vegetation are the fundamental indicators that reflect the evolution of the ecological environment, while soil organic carbon affects soil nutrient migration and vegetation restoration in bare land. However, the total organic carbon content is a result of the balance between carbon accumulation and mineralization in the soil and cannot reflect the evolution of regional soil quality and responses to mining disturbances. The structure and composition of dissolved organic matter (DOM) affect the activity and ecological effects of DOM in soil. DOM is the active organic matter in soil and can influence the migration and transformation of nutrients and pollutants, as well as respond to the succession of ecosystems and surface vegetation [5]. The reactivity of DOM directly depends on its content and compositional and structural characteristics [6]. The activities of plants and microorganisms can significantly impact the DOM content. Moreover, DOM can be easily decomposed by oxidation [7]. The composition and structure of soil DOM varies dynamically with soil organic carbon, reflecting short-term soil carbon dynamics. Such minor variations can predict the long-term evolution trend of DOM. Therefore, DOM has gradually become an important indicator for evaluating soil quality that is widely used in soil management [8]. We conducted an in-depth analysis of DOM composition and structural characteristics at the vegetation-soil interface over 7 years of dump existence. The original dump is characterized by mining disturbances, allowing us to reveal the trend of organic carbon migration and transformation at the vegetation-soil interface.

The western region of China (provinces of Shanxi, Shaanxi, Mongolia, Gansu, and Ningxia) is the main coal-producing area. It is characterized by rare rainfall events and significant soil desertification. The contradiction between coal resource development and environmental protection has become prominent, and there is an urgent need to reveal how coal mining disturbances affect the regional soil environment. With the development of spectroscopy technology, ultravioletvisible (UV-vis) absorption spectroscopy and excitationemission matrix (EEM) fluorescence spectroscopy have been widely used to study the composition and structural characteristics of DOM in natural water, soil, and other ecosystems [9-11]. These spectroscopic techniques reflect the aromaticity and molecular weight of DOM components, and can evaluate their structural stability, characterize fluorescent components, and identify their material sources. The research on DOM in coal mining areas mainly focuses on the relationship between components and heavy metals [12-14]. At present, there is a lack of relevant research on the migration and change laws of composition and structural features. Thus, in order to better estimate the dynamic change and restoration status of the vegetationsoil interface in coal mining areas, it is important to study the composition and structure of DOM.

This study applies a variety of spectroscopy techniques and analysis methods to analyze the DOM components and structural characteristics at the vegetation-soil interface of a mining dump. We investigated the relationships between the DOM components, its structural characteristics at the vegetation-soil interface, and various forms of carbon content. We also clarified the main factors controlling the dynamic carbon content at the vegetation-soil interface. Overall, this study can further disclose the issues regarding soil protection in open-pit coal mine dumps and provide a theoretical basis for assessing the ecological environment and ecological restoration in coal mining areas.

\section{Materials and Methods}

\section{Sample Collection and Pretreatment}

This study was conducted in the Xilinhot open-pit

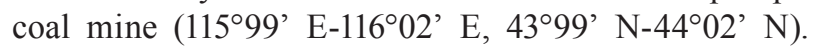
The mining area represents a typical dry grassland, with an average annual rainfall of approximately 250-400 $\mathrm{mm}$ (July-September) and an average annual temperature of approximately $1.7^{\circ} \mathrm{C}$ [15]. The mining area was established in September 2007, and a stripped slag dump was created in the surrounding area. The dump has an irregular quadrilateral shape with alternating platforms and slopes, showing a stepped topography (Fig. 1). To minimize the impact of individual soil characteristics on determinant soil properties, all samples were obtained from sites with a similar topography, altitude, and geographic coordinates. In July 2019, we collected representative soils from the sampling sites where the dump existed for 1, 3, 5, and 7 years, as well as from the original grassland soil. The characteristics of each sampling site are listed in Table 1 . The vegetation-soil interface with approximately 0-20 cm of soil was sampled by columnar sampler, and were sealed in a zip-lock bag. They were brought back to the laboratory to be freeze-dried, ground and passed through a 100-mesh sieve. After sieving, the samples were washed with Milli-Q ultrapure water (water: soil (v/w): 10:1). The supernatant was filtered through a 



Fig. 1. Geographic location of the study area and sampling sites.

$0.45-\mu \mathrm{m}$ pore size membrane after being oscillated at $220 \mathrm{r} / \mathrm{min}$ for $16 \mathrm{~h}$ and centrifuged at $8,000 \mathrm{rpm}$ for $15 \mathrm{~min}$. The filtrate was then refrigerated at $4^{\circ} \mathrm{C}$ under dark conditions until the analysis.

Determination of Total Nitrogen, Total Phosphorus, and Carbon Content

The total phosphorus (TP) and total nitrogen (TN) contents of the samples were calculated using a KDY-5000 Kjeldahl analyzer, according to the microKjeldahl method. The dissolved organic carbon (DOC), dissolved inorganic carbon (DIC), and dissolved total carbon (DTC) contents in all the samples were analyzed using a TOC-5000 total organic carbon analyzer (Shimadzu, Japan). The soil $\mathrm{pH}$ was measured using the potentiometric method (water: soil (v/w): 2.5:1).

\section{Ultraviolet-Visible Spectra}

DOM was determined using a 1-cm quartz cuvette on a DR-5000 spectrophotometer (Hach, USA) in a wavelength range of 200-700 nm. SUVA ${ }_{254}$ was derived from the absorbance at $254 \mathrm{~nm} / \mathrm{DOC}$ concentration. $\mathrm{A}_{253} / \mathrm{A}_{203}$ was calculated from the ratio of the absorbance at $253 \mathrm{~nm}$ to that at $203 \mathrm{~nm}$ [16-17]. $\mathrm{E}_{2} / \mathrm{E}_{3}$ was obtained from the ratio of the absorbance at $250 \mathrm{~nm}$ to that at $365 \mathrm{~nm}[18]$.

\section{Fluorescence Spectroscopy}

An F-7000 fluorescence spectrometer (Hitachi, Japan) was used to obtain the fluorescence spectra. The scanning speed was $2,400 \mathrm{~nm} / \mathrm{min}$, and the scanning bandwidth was $5 \mathrm{~nm}$. The emission and excitation wavelengths were set at $200-450 \mathrm{~nm}$ (5-nm intervals) and $250-600 \mathrm{~nm}$ (5-nm intervals), respectively. The EEM spectra were quantitatively obtained using fluorescence reflectance imaging (FRI) [19]. The fluorescence index (FI) was determined by the emission intensity at wavelengths of 450 and $500 \mathrm{~nm}$, when the excitation wavelength was $370 \mathrm{~nm}$ [20]. The biological index (BIX) refers to the ratio of fluorescence intensity at emission wavelengths of 380 and $430 \mathrm{~nm}$, when the excitation wavelength is $310 \mathrm{~nm}$ [21].

Table 1. Characteristics of each sampling site.

\begin{tabular}{|c|c|c|}
\hline Area & Sample & Vegetation Types \\
\hline \multirow{3}{*}{ Disturbance area } & 1-year (S1) & Ephemeral plants \\
\cline { 2 - 3 } & 3-year (S2) & Sparsely distributed ephemeral plants in clusters, 0-2 species of plants $/ \mathrm{m}^{2}$ \\
\cline { 2 - 3 } & 5-year (S3) & Sparsely distributed perennial xerophyte community, 0-3 plants $/ \mathrm{m}^{2}$ \\
\cline { 2 - 3 } & 7-year (S4) & Grassland vegetation in arid sandy land, 6-7 plants $/ \mathrm{m}^{2}$ \\
\hline Undisturbed area & Grassland (S5) & \\
\hline
\end{tabular}




\section{Data Analysis}

Origin 8.0 and Excel 2017 were utilized to analyze and process the data. SPSS 17.0 was used for the cluster analysis of different parameters, whereas MATLAB 2012a was used to draw the fluorescence spectra combined with the spectral partition analysis.

\section{Results and Discussion}

\author{
Physical and Chemical Properties \\ of the Vegetation-Soil Interface and \\ Spatio-Temporal Distribution \\ of Carbon Contents
}

Table 2 shows the general physical and chemical characteristics of the vegetation-soil interface in different areas of the Xilinhot open-pit coal dump. The DOM content was expressed as the DOC concentration and varied between 320.28 and $403.81 \mathrm{mg} / \mathrm{kg}$ at the vegetation-soil interface, decreasing in the first 1-3 years and increasing in years 5-7. The DIC content was 242.85-918.86 $\mathrm{mg} / \mathrm{kg}$, and the $\mathrm{pH}$ value and TP content both had a $\mathrm{S} 2>\mathrm{S} 1>\mathrm{S} 4>\mathrm{S} 3$ fluctuation trend. The TN content increased with the increase in dump age. Compared with the grassland, the vegetation-soil interface parameters of the dump differed significantly over the years. With an increase in dump age, the vegetation-soil interface parameters gradually returned to the level in grassland soil, while the $\mathrm{pH}$ value showed the same trend as the content of TP and DIC. Soil $\mathrm{pH}$ affects the level of nutrients and the content of carbon components in soils [22-23], whereas different vegetation types affect the soil nutrients and carbon content [24-25]. Herein, we primarily focused on the effects of soil $\mathrm{pH}$ and vegetation types on the content of various carbon components at the vegetation-soil interface in the dump.

\section{Ultraviolet-Visible Spectral Characteristics of DOM}

The SUVA $_{254}$ value is widely used to estimate the aromatic content of DOM. SUVA ${ }_{254}$ values of less than 3 indicate that natural organics contain specific hydrophilic substances [26-27]. As shown in Table 3, the $\mathrm{SUVA}_{254}$ value at the vegetation-soil interface in the disturbed and undisturbed areas varied from 0.005 to 0.058 , which is significantly lower than 3 . Such low values indicate that DOM at the vegetationsoil interface in both regions was mainly composed of hydrophilic substances. The $\mathrm{SUVA}_{254}$ value at the vegetation-soil interface in the disturbed area ranged between 0.005 and 0.058 , presenting an increasing trend in the first 1-3 years and a decreasing trend in years 5-7 of dump existence. A higher molecular weight and degree of humification of DOM leads to more difficult degradation and a lower activity of microorganisms [28]. As such, the degree of humification and aromatization of DOM at the vegetation-soil interface in the 3-year dump was higher, but the microbial activity was weaker. Ephemeral plants in the 3-year dump belonged to the adaptation stage. The plants competed with soil microorganisms for nutrients, which resulted in weak microbial activity and prevented soil microorganisms from degrading vegetation litter. When the dump vegetation in the disturbed area gradually adapted to the soil interface over years 5-7, the microbial activity was gradually restored along with the ecological processes (e.g., plant growth, metabolism). However, the degree of DOM molecular humification at the vegetation-soil interface of the dump gradually decreased between years 5 and 7 . This may be related to the sparse distribution of plants, shorter root systems and restoration of microbial activity, resulting in less litter biomass and soil humus accumulation.

The $\mathrm{A}_{253} / \mathrm{A}_{203}$ ratio can be used to indicate the concentration of substitution groups, where higher $\mathrm{A}_{253} / \mathrm{A}_{203}$ ratios correspond to the substitution in aromatic rings with carbonyl, carboxyl, hydroxyl, and ester groups [29]. The $\mathrm{A}_{253} / \mathrm{A}_{203}$ ratio at the vegetationsoil interface in the disturbed area ranged between 0.066 and 1.126, decreasing as the dump matured (Table 3). Such a decrease indicates that the aromatic ring structures of DOM at the vegetation-soil interface in the 7-year dump contained more aliphatic chains and fewer carbonyl, carboxyl, hydroxyl, and ester groups. According to Li et al [29], active functional groups (e.g., carbonyl, carboxyl, and hydroxyl) may affect organic matter, metal ions, and toxic reactive pollutants in the soil owing to adsorption, oxidation, complexation, and reduction. This means that

Table 2. Physical and chemical properties of the vegetation-soil interface.

\begin{tabular}{|c|c|c|c|c|c|c|}
\hline Sample & DTC $\left(\mathrm{mg} \cdot \mathrm{kg}^{-1}\right)$ & DOC $\left(\mathrm{mg} \cdot \mathrm{kg}^{-1}\right)$ & DIC $\left(\mathrm{mg} \cdot \mathrm{kg}^{-1}\right)$ & TN $\left(\mathrm{mg} \cdot \mathrm{kg}^{-1}\right)$ & TP $\left(\mathrm{mg}^{\mathrm{kg}} \mathrm{kg}^{-1}\right)$ & $\mathrm{pH}$ \\
\hline S1 & $1,167.71 \pm 204.59$ & $403.81 \pm 16.19$ & $763.90 \pm 128.52$ & $33.97 \pm 1.12$ & $219.27 \pm 6.22$ & $8.27 \pm 0.85$ \\
\hline S2 & $1,239.14 \pm 153.91$ & $320.28 \pm 21.52$ & $918.86 \pm 32.37$ & $49.56 \pm 2.02$ & $451.21 \pm 9.56$ & $8.32 \pm 0.72$ \\
\hline S3 & $573.67 \pm 21.60$ & $330.82 \pm 2.41$ & $242.85 \pm 24.04$ & $172.01 \pm 5.71$ & $159.52 \pm 3.82$ & $5.83 \pm 0.93$ \\
\hline S4 & $857.56 \pm 274.22$ & $401.43 \pm 14.60$ & $456.13 \pm 219.73$ & $709.93 \pm 7.42$ & $238.35 \pm 5.21$ & $6.45 \pm 0.69$ \\
\hline S5 & $923.13 \pm 202.28$ & $434.91 \pm 19.72$ & $488.22 \pm 122.57$ & $961.28 \pm 6.29$ & $162.85 \pm 4.26$ & $7.79 \pm 0.71$ \\
\hline
\end{tabular}


Table 3. UV-vis parameters and fluorescence indices of the vegetation-soil interface.

\begin{tabular}{|c|c|c|c|c|c|}
\hline Sample & SUVA $_{254}$ & $\mathrm{~A}_{253} / \mathrm{A}_{203}$ & $\mathrm{E}_{2} / \mathrm{E}_{3}$ & FI & BIX \\
\hline $\mathrm{S} 1$ & $0.044 \pm 0.001$ & $1.126 \pm 0.551$ & $4.441 \pm 0.061$ & $2.461 \pm 0.542$ & $1.142 \pm 0.466$ \\
\hline $\mathrm{S} 2$ & $0.058 \pm 0.002$ & $0.715 \pm 0.392$ & $4.131 \pm 0.362$ & $1.962 \pm 0.049$ & $1.211 \pm 0.088$ \\
\hline $\mathrm{S} 3$ & $0.017 \pm 0.007$ & $0.110 \pm 0.041$ & $3.002 \pm 0.201$ & $2.133 \pm 0.180$ & $1.540 \pm 0.058$ \\
\hline S4 & $0.005 \pm 0.001$ & $0.066 \pm 0.023$ & $2.300 \pm 0.700$ & $2.020 \pm 0.231$ & $1.142 \pm 0.175$ \\
\hline S5 & $0.049 \pm 0.002$ & $0.712 \pm 0.180$ & $4.352 \pm 0.511$ & $2.681 \pm 0.052$ & $0.951 \pm 0.351$ \\
\hline
\end{tabular}

the DOM adsorption, oxidation, and reduction capabilities of the vegetation-soil interface decrease during dump recovery, increasing the potential risk of pollution at the vegetation-soil interface.

The $E_{2} / E_{3}$ ratio generally indicates the source of organic matter. If the value is less than 3.5 , the content of fulvic acid in the organic matter is less than that of humic acid. On the contrary, when the value is greater than 3.5, the content of fulvic acid in the organic matter is greater than that of humic acid [30]. As shown in Table 3, the $\mathrm{E}_{2} / \mathrm{E}_{3}$ ratio at the vegetation-soil interface in the disturbed area ranged between 2.300 and 4.441, decreasing with the increase in dump age (Table 3 ). The results showed that the content of humic acid in DOM at the vegetation-soil interface gradually increased with increasing dump age. The newly formed humic acid was relatively fatty and had high reactivity, which was conducive to the transformation of soil organic matter, the release of nutrients, and the formation of soil structures [31-32]. Therefore, the newly formed humic acid content at the vegetation-soil interface increased with dump recovery, improving vegetation-soil interface fertility.

Furthermore, the $\mathrm{SUVA}_{254}$ value, $\mathrm{A}_{253} / \mathrm{A}_{203}$ ratio, and $\mathrm{E}_{2} / \mathrm{E}_{3}$ ratio at the vegetation-soil interface in the first 1-3 years of the dump were greater than or close to those of the grassland. Therefore, the humification degree, substituent types, and fulvic acid content of DOM at the vegetation-soil interface (1-3 years) were also close to those of the grassland. However, the $\mathrm{SUVA}_{254}$ value, $\mathrm{A}_{253} / \mathrm{A}_{203}$ ratio, and $\mathrm{E}_{2} / \mathrm{E}_{3}$ ratio at the vegetation-soil interface in the 5-7-year-old dump were significantly lower than those of the grassland, indicating that the humification degree, substituent types, and fulvic acid content of DOM at the vegetation-soil interface (5-7 years) decreased sharply. Such a sharp decrease means that the physical and chemical properties of the vegetation-soil interface of the dump improved over the years, but the composition and structure of DOM deteriorated. Thus, the government should not only rely on physical and chemical parameters to evaluate the degree of soil recovery but also consider soil DOM components and structural characteristics when implementing recovery measures.

\section{Fluorescence Spectral Characteristics of DOM}

The FI value was used to determine the source of organic matter. An FI value near 1.3 indicates a terrestrial DOM source, while a value near 1.8 indicates a microbial DOM source [20]. The BIX value is an indicator correlated with the biological contribution of DOM [21]. If the BIX value is greater than 1, the corresponding DOM is principally derived from bacteria, organisms, and their metabolites. However, if the BIX value is between 0.6 and 0.7 , the corresponding DOM is primarily obtained from terrestrial plants [21]. The FI value at the vegetation-soil interface in the disturbed and undisturbed areas of the dump equaled 1.962 and 2.681, respectively, while the BIX value ranged between 0.951 and 1.540 (Table 3). These results indicate that the DOM at the vegetation-soil interface in both dump regions originated from microbial sources. Thus, we argue that microorganisms and their metabolites play an important role in the remediation of the vegetation-soil interface, and that the degree of humification and the type of substituents of DOM are significantly affected by microbial activity.

The EEM-FRI technology was used to further study the DOM composition at the vegetation-soil interface in different disturbed dump areas. According to Zhang et al. [33], five regions of fluorescence spectra were derived by fluorescence regional integration (FRI). These five regions were divided into three substance types, $\mathrm{P}_{(\mathrm{I}+\mathrm{II}, n)}, \mathrm{P}_{(\mathrm{III}+\mathrm{V}, n)}$, and $\mathrm{P}_{(\mathrm{IV}, n)}$, which represent simple proteins, complex humic substances, and soluble microbial metabolites, respectively (Fig. 2).

The EEM-FRI analysis results showed that DOM at the vegetation-soil interface of the dump mainly contained humic-like substances and few protein-like substances (Fig. 3). The proportion of simple aromatic proteins first increased (years 1-5) and then decreased (years 5-7). The proportion of humus complex organic matter showed a decreasing trend, and the proportion of microbial metabolites decreased first (years 1-5) and then increased (years 5-7). The DOM of the vegetationsoil interface in the dump mainly originated from microbial sources. Meanwhile, under the influence of coal evolution and environmental factors (e.g., rainfall, 

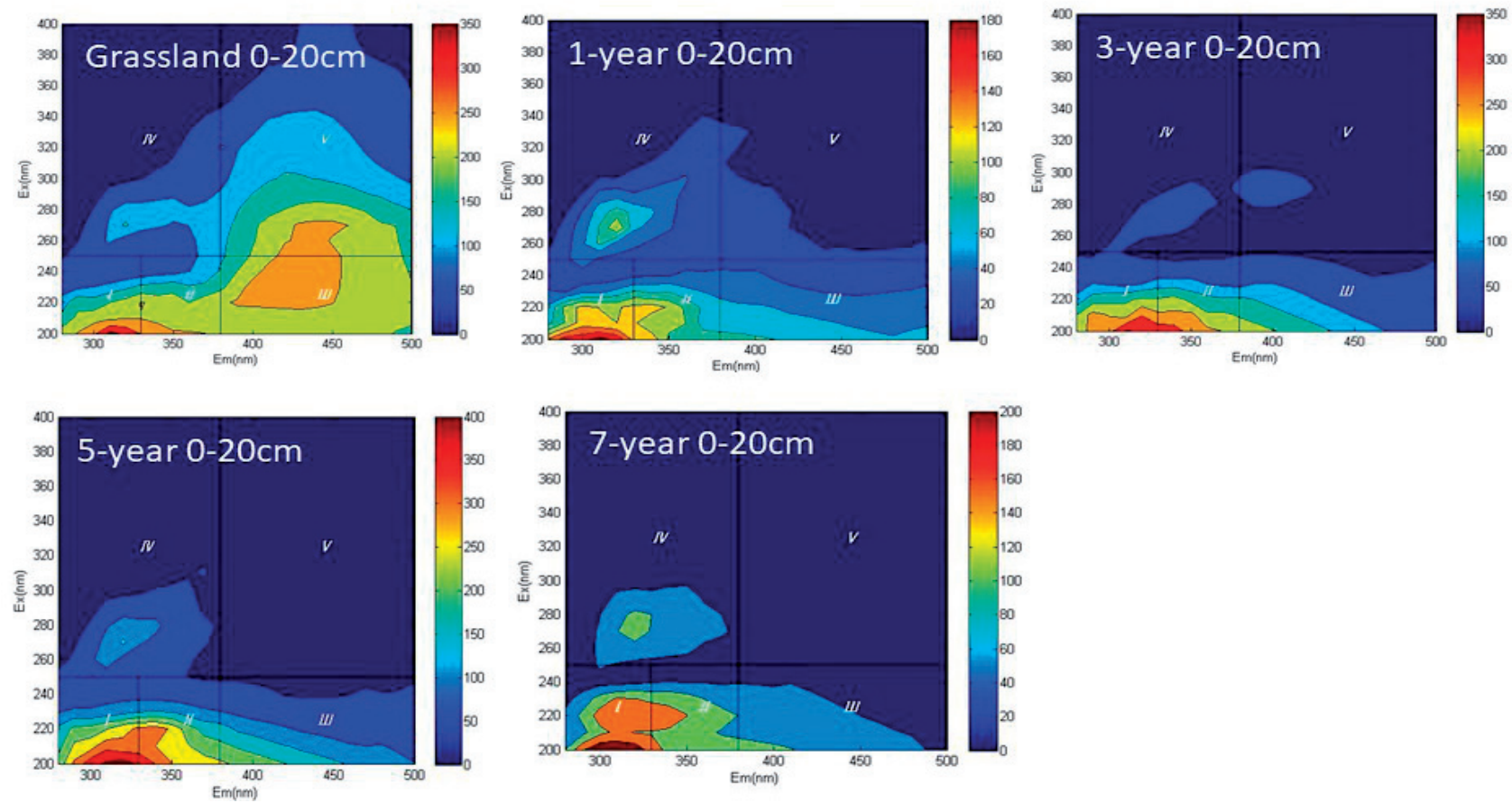

Fig. 2. EEM spectra of DOM at the vegetation-soil interface.

light), a large amount of autochthonous DOM can be released by plants in the soil-vegetation interface [34-35]. Generally, most of the proteins and carbohydrates produced by this process can be quickly consumed and utilized by microorganisms, accompanied by the release of nutrients and the accumulation of smaller, more refractory autochthonous humus [36]. However, the proportion of simple aromatic proteins first increased (years 1-5) may be mainly due to the inadequate reaction due to low microbial activity. Notably, the vegetation-soil interface of the 7-year-old dump was dominated by sparsely distributed perennial xerophyte communities and gradually adapted to the soil, which may promote the increase of microbial activity and lead to significant changes in DOM components. This is to say, large amounts of protein substances are degraded and utilized by microorganisms in the vegetation-soil interface, accompanied by an increase in the proportion of microbial metabolites. In addition, hydrophobicity and hydrogen bonding are considered to be the main mechanisms that help stabilize humus [37]. With changing environmental conditions, the interspersion of simple organic molecules in the structure of humus may disrupt its stable structure



Fig. 3. $\mathrm{P}_{(\mathrm{i}, n)}$ percentage of DOM at the vegetation-soil interface. 
[38-39]. DOM at the vegetation-soil interface of the dump was composed of hydrophilic substances and fatty chains, meaning that the humic-like substances at the vegetation-soil interface of the dump were unstable, and some of them could be easily degraded to be utilized by microorganisms. Thus, this rationale may explain why the proportion of humic-like substances in DOM at the vegetation-soil interface gradually decreased.

DOM at the grassland vegetation-soil interface was primarily composed of humic-like substances (60\%), proteins (24\%), and microbial metabolites (16\%); the proportion of humic-like substances in the grassland was significantly higher than that in the dump, contrary to the protein content. This meant that there was a significant gap between the DOM composition of the vegetation-soil interface in the dumping site and that of the grassland. Thus, nutrients should be appropriately added to improve the microbial activity in the initial recovery stage of the dump, which is beneficial to the rapid recovery of soil and vegetation.

\section{Environmental Impact of the Vegetation-Soil Interface}

To find similarities between the DOM structural characteristics at the vegetation-soil interface and soil indicators, we investigated the relationships between different soil parameters. Herein, we employed a hierarchical cluster analysis, where four main clusters were observed at a rescaled distance (Fig. 4). The rescaled distance between $B I X$ and $\mathrm{P}_{(\mathrm{I}+\mathrm{II}, n)}$ was smaller and formed the first cluster, thereby suggesting that the microbial metabolites at the vegetation-soil interface affected the protein content. The DOC, TN, and $\mathrm{P}_{(\mathrm{III}+\mathrm{V}, n)}$ formed the second cluster, implying that DOM content affected humic-like substances and TN content at the vegetation-soil interface. The third cluster was formed by FI, $\mathrm{P}_{(\mathrm{III}+\mathrm{V}, n)} / \mathrm{P}_{(\mathrm{I}+\mathrm{II}, n)}$, and $\mathrm{P}_{(\mathrm{IV}, n)}$, suggesting that the content of humic-like substances and microbial metabolites at the vegetation-soil interface was predominantly affected by the source of microorganisms. The fourth cluster was formed by SUVA $_{254}, \mathrm{~A}_{253} / \mathrm{A}_{203}, \mathrm{E}_{2} / \mathrm{E}_{3}, \mathrm{DIC}$, DTC, and $\mathrm{pH}$, indicating that the $\mathrm{pH}$ of the vegetation-soil interface was crucial for the composition and structure of DOM and the spatio-temporal distribution of carbon content.

To further identify the relationships between the structural characteristics of DOM and carbon components at the vegetation-soil interface and to reveal the environmental impact, we evaluated the relationships among the spectroscopic parameters of DOM, DOC, and DIC at the vegetation-soil interface using linear analysis. As shown in Fig. 5a), the ratio of humic-like to protein-like substances $\left(\mathrm{P}_{(\mathrm{III}+\mathrm{V}, n)} / \mathrm{P}_{(\mathrm{I}+\mathrm{II}, n)}\right)$ had a significantly positive correlation with the content of DOC and $\mathrm{pH}(r=0.487-0.533 ; P<0.01)$, indicating that the proportion of humus components is related to the DOM content and $\mathrm{PH}$ value in the vegetation-soil interface. Moreover, the DOC content at the vegetationsoil interface was closely related to the FI and BIX



Fig. 4. Cluster analysis of different soil parameters. 
values in Fig. 5b) ( $r=0.578-0.676, P<0.01)$, suggesting that the soil DOC content was mainly affected by the microbial activity. In this study, the vegetation-soil interface has the characteristics of strong contribution from autochthonous. Generally, part of the DOM in the litter can be degraded and utilized by microorganisms, accompanied by the release of nutrients and the accumulation of more refractory autochthonous DOM [36]. Meanwhile, humus with more negatively charged functional groups has the characteristic of adsorbing heavy metal cations and carries, promoting the production of $\mathrm{OH}^{-}$[40]. Thus, these results showed that the DOM composition and content at the vegetation-soil interface of the dump were substantially affected by microbial activities. In addition, $\mathrm{A}_{253} / \mathrm{A}_{203}$ and SUVA $_{254}$ were significantly correlated with the soil $\mathrm{pH}$ and DIC content $(r=0.543-0.839, P<0.01)$ (Figs 5(c-d)), demonstrating that the DOM aromatic ring substituents and the degree of humification were closely related to DIC and $\mathrm{pH}$. This finding was related to the high humification degree rendered DOM difficult to degrade and metal cations can be adsorbed by carbonyl, carboxyl, and hydroxyl groups [16]. In short, when the degree of soil DOM humification and the content of carbonyl, carboxyl, and hydroxyl groups in the aromatic ring substituents were high, the DIC content and $\mathrm{pH}$ value also increased. To conclude, the structural characteristics of DOM at the vegetationsoil interface were closely related to the different forms of carbon in the soil. Thus, under certain conditions (e.g., terrestrial pollution, microbial degradation, redox potential), soil $\mathrm{pH}$ can be used to indirectly reflect the structural characteristics of DOM and the spatiotemporal changes in various forms of carbon content.

\section{Dynamic Change in Various Forms of Carbon Content}

To clarify the dynamic change in various forms of carbon at the vegetation-soil interface of the dump, we explored the effects of vegetation restoration and soil $\mathrm{pH}$ on the content of various forms of carbon.

With increasing dump age, the DOM content at the vegetation-soil interface decreased in years 1-3 and then increased in years 5-7. We suggested that the main reason for the decline in the DOM content in the first 3 years of dump existence is the adaptation stage of ephemeral plants and the imbalance between DOM consumption and input by plants into the soil system [41]. However, the roots of ephemeral plants were distributed in sparse clusters when the dump was 5-year-old. Such scattered roots secreted more small- a)

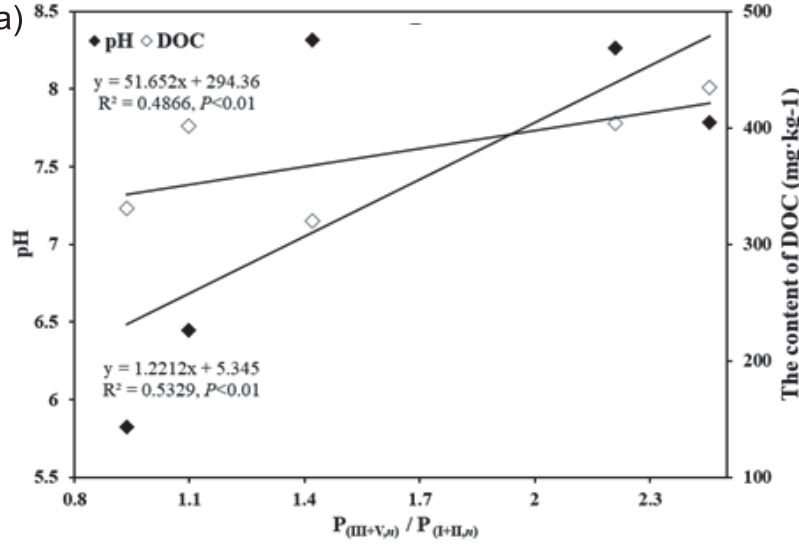

b)

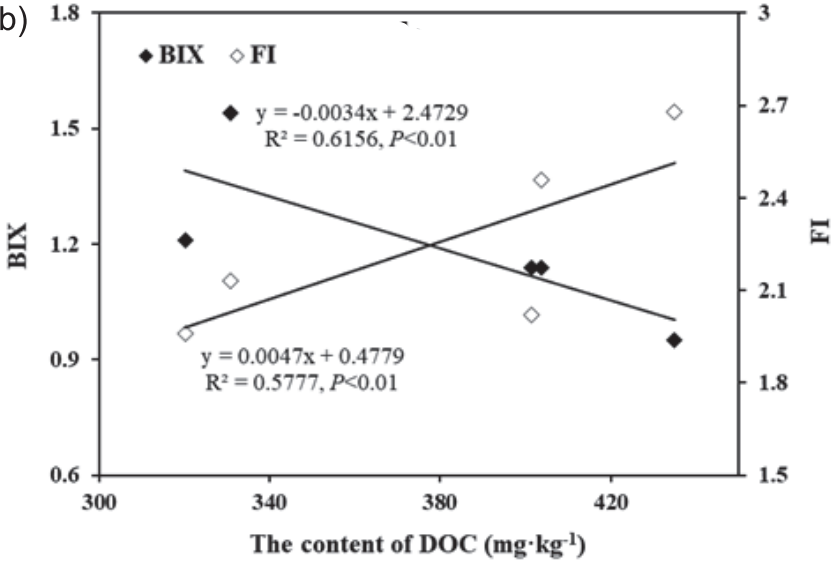

C)

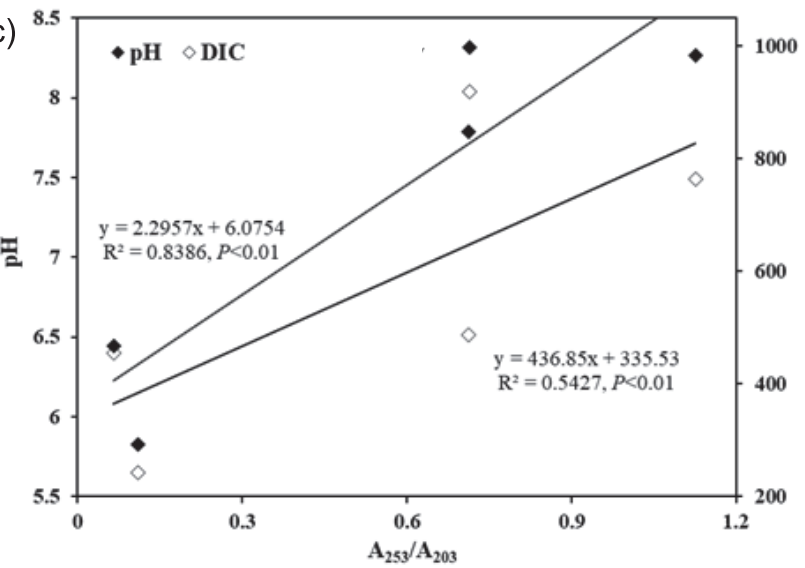

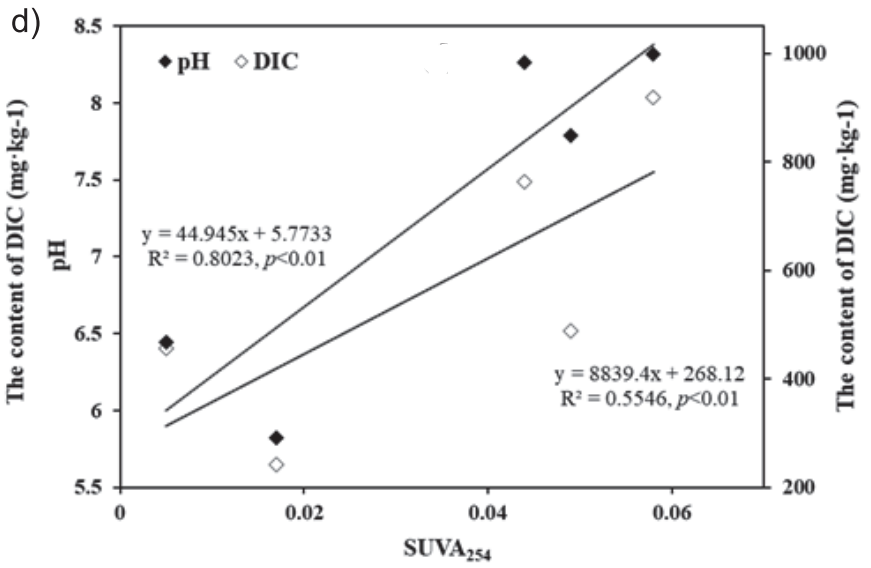

Fig. 5. Relationship between the characteristics of DOM components and the content of different carbon forms in the soil. 
molecule organic acids into the soil, causing the soil to become acidic [42]. In turn, acidic soil inhibited microbial activity and reduced the decomposition efficiency of organic matter, resulting in the stagnation of the DOC content [43]. The 7-year-old dump was dominated by sparsely distributed perennial xerophyte communities. These plant communities adapted rapidly to the soil so that the associated microorganisms had sufficient nutrients and were characterized by high activity. As such, the 7-year-old dump DOM had a low degree of humification and a simple molecular structure. Plant leaves were likely degraded under the action of microorganisms, providing large amounts of DOM at the vegetation-soil interface and restoring the contents of $\mathrm{N}$ and $\mathrm{P}$ in the soil to a certain extent.

The DIC content was the highest at 3 years, followed by that at 1,7 , and 5 years. Crystal cells in the root hair and root sheath of plants are known to contain calcium carbonate in the form of stalactites [44]. This meant that the ephemeral plant residues in the 3 -year-old dump were accompanied by the formation of calcium carbonate, which increased the vegetationsoil interface DIC content. Meanwhile, the low $\mathrm{pH}$ of the 5-year-old dump caused the soil inorganic carbon to be converted into a gas form, which was released into the atmosphere, thereby decreasing the DIC content in the soil [45]. In addition, with the growth of plant rhizomes and the enhancement of microbial respiration in the 7-year dump, the release of $\mathrm{CO}_{2}$ increased, which led to the increase of DIC content at the vegetation-soil interface.

As shown above, the soil physical and chemical properties and content of various forms of carbon slightly improved in the process of vegetation-soil restoration of the dump. Vegetation changes affected soil respiration, changed the mineralization and decomposition of soil organic carbon, and affected soil carbon release. Plant metabolites and residues were the main organic carbon sources in the soil, and played a key role in soil carbon sequestration. At the same time, the soil $\mathrm{pH}$ significantly affected the quantity and activity of soil microorganisms and their action on carbon transformation. Furthermore, the soil $\mathrm{pH}$ controlled the cyclic transformation process of soil nutrients, the turnover capacity of soil carbon content, and the productivity of the ecosystem. Thus, the government should pay attention to soil $\mathrm{pH}$ and vegetation types when implementing effective management policies of dump in the future. Meanwhile, it is necessary to increase the investment in reclamation of the dump and adjust the vegetation type of the dump in a timely and appropriate manner, which is conducive to the rapid restoration of the dump.

\section{Conclusions}

Based on the combination of UV-Vis and 3DEEM spectroscopy, the DOM components and structural characteristics at the vegetation-soil interface and the distribution characteristics of different forms of carbon were analyzed. The results showed that the DOM and DIC contents at the vegetation-soil interface of the dump were $320.82-403.81$ and $242.85-918.86 \mathrm{mg} / \mathrm{kg}$, respectively. Meanwhile, DOM at the vegetationsoil interface of the dump was mainly composed of hydrophilic substances. Under the dominance of microbial sources, the DOM components of the vegetation-soil interface were mainly humic-like and protein-like substances. With increasing dump age, the content of fatty chains and newly formed humic acid in DOM increased. In addition, soil $\mathrm{pH}$ can be used to indirectly reflect the humification degree of DOM and the spatio-temporal changes in various forms of carbon content.

This study enhances the understanding of the migration and transformation mechanisms of carbon components at the vegetation-soil interface of a coalmining dump. However, a clear characterization of carbon components at the vegetation-soil interface is still lacking. In our future research, we will use Fourier transform ion cyclotron resonance mass spectrometry to elucidate the structure of DOM and the chemical properties of soil carbon at the vegetation-soil interface at the molecular level in order to reveal the mechanism of carbon migration and transformation at the vegetation-soil interface of coal mining dumps.

\section{Acknowledgments}

This work is supported by Beijing Major Science and Technology Projects (Z181100005318001), and Open Fund of State Key Laboratory of Water Resource Protection and Utilization in Coal Mining (Grant No. GJNY-18-73.18).

\section{Conflict of Interest}

The authors declare no conflict of interest.

\section{References}

1. BI Y., ZHANG Y., ZOU H. Plant growth and their root development after inoculation of arbuscular mycorrhizal fungi in coal mine subsided areas. Int. J. Intell. Syst. 5 (1), 47, 2018.

2. WANG T., XUE Y., BAO Y., QI Y., QU Y., DONG M. Soil organic carbon content of the spoiled bank under different reclamation modes, Heidaigou open pit, Inner Mongolia. J. Saf. Environ. 14, 174, 2014.

3. ZHANG Z., WANG J M., LI B. Determining the influence factors of soil organic carbon stock in opencast coal-mine dumps based on complex network theory. Catena. 173, 433, 2019.

4. LI X., LEI S., LIU F., WANG W. Analysis of plant and soil restoration process and degree of refuse dumps in open-pit 
coal mining areas. INT J ENV RES PUB HE. 17 (6), 1975, 2020.

5. BAI J., ZHAO Q., LU Q., GAO Z., REDDY K. Effects of freshwater input on trace element pollution in salt marsh soils of a typical coastal estuary, China. J. Hydrol. 520, 186, 2015.

6. GUEGUEN C., BURNS D C., MCDONALD A., RING B. Structural and optical characterization of dissolved organic matter from the lower Athabasca River, Canada. Chemosphere. 87 (8), 932, 2012.

7. SHARMA P., LAOR Y., RAVIV M., MEDINA S., SAADI L., KRASNOVSKY A., VAGER M., LEVY G.J., BAR T.A., BORISOVER M., Compositional characteristics of organic matter and its water-extractable components across a profile of organically managed soil. Geoderma. 286, 73, 2017.

8. TANG J., WANG W., YANG L., CAO C., LI X. Variation in quantity and chemical composition of soil dissolved organic matter in a peri-urban critical zone observatory watershed in eastern china. Sci. Total Environ. 688, 2019.

9. WEI M., GAO C., ZHOU Y., DUAN P., LI M. Variation in spectral characteristics of dissolved organic matter in inland rivers in various trophic states, and their relationship with phytoplankton. Ecol. Indic. 321, 2019.

10. LIU Y., YE Q., HUANG W., FENG L., WANG Y., XIE Z., YONG S., ZHANG S., JIANG B., ZHENG Y., WANG J. Spectroscopic and molecular-level characteristics of dissolved organic matter in the Pearl River Estuary, South China. Sci. Total Environ. 710, 136307, 2019.

11. MUSADJI N.Y., LEMEE L., CANER L., POREL G., POINOT R., GEFFROY R.C. Spectral characteristics of soil dissolved organic matter: Long-term effects of exogenous organic matter on soil organic matter and spatial-temporal changes. Chemosphere. 240, 2020.

12. CHEN W., PENG L., HU K., ZHANG Z., ZHOU K. Spectroscopic response of soil organic matter in mining area to $\mathrm{pb} / \mathrm{cd}$ heavy metal interaction: a mirror of coherent structural variation. J HAZARD MATER. 393, 122425, 2020.

13. GUO X., XIE X., LIU Y., WANG C., HUANG Y. Effects of digestate dom on chemical behavior of soil heavy metals in an abandoned copper mining areas. J HAZARD MATER. 393, 122436, 2020.

14. KAI Z.A., JU G.A., DM B., XZ A., SW A. Insight into the heavy metal binding properties of dissolved organic matter in mine water affected by water-rock interaction of coal seam goaf. Chemosphere. 2020.

15. LEI S.G., REN L.X., BIAN Z.F. Time-space characterization of vegetation in a semiarid mining area using empirical orthogonal function decomposition of MODIS NDVI time series. Environ. Earth. Sci. 75 (6), 516, 2016.

16. ZHANG L., WANG S.R., ZHAO H.C., LI Y.P., HUO S.L., QIAN W.B., YAN Y.L., CHEN J. Using multiple combined analytical techniques to characterize water extractable organic nitrogen from Lake Erhai sediment. Sci. Total Environ. 344, 2016.

17. ZHANG L., WANG S.R., XU Y.S., SHI Q., ZHAO H.C., JIANG B., YANG J.C. Molecular characterization of lake sediment WEON by Fourier transform ion cyclotron resonance mass spectrometry and its environmental implications. Water Res. 196, 2016.

18. MIAO S., LYU H., WANG Q., LI Y., WU Z., DU C., XU J., BI S., MU M., LEI S. Estimation of terrestrial humiclike substances in inland lakes based on the optical and fluorescence characteristics of chromophoric dissolved organic matter (CDOM) using OLCI images. Ecol. Indicat. 101, 399, 2019

19. ZHANG L., LIU H., WANG Y., PENG Y. Compositional characteristics of dissolved organic matter during coal liquefaction wastewater treatment and its environmental implications. Sci. Total Environ. 704, 135409, 2020.

20. ZHANG L., XU K., WANG S., LI Y., LI Q., MENG Z. Characteristics of dissolved organic nitrogen in overlying water of typical lakes of Yunnan Plateau, China. Ecol. Indic. 84, 727, 2018

21. LI Y., ZHANG L., WANG S., ZHAO H., ZHANG R. Composition, structural characteristics and indication of water quality of dissolved organic matter in Dongting Lake sediments. Ecol. Eng. 97, 370, 2016.

22. HUANG Y., LI Y., XIAO Y., WENIGMANN K.O., ZHOU G.Y., ZHANG D.Q., WENIGMANN M., TANG X.T., LIU J.X. Controls of litter quality on the carbon sink in soils through partitioning the products of decomposing litter in a forest succession series in South China. For. Ecol. Manag. 261 (7), 1170, 2011.

23. OUIMET R., MOORE J.D. Effects of fertilization and liming on tree growth, vitality and nutrient status in boreal balsam fir stands. For Ecol Manag. 345, 39, 2015.

24. MA Y.H., GUO S.L., YANG Y.L., WANG X.L., YANG G. Influence of Vegetation Types on Soil Organic $\mathrm{C}$ at Yangou Catchment in the Loess Hilly-gully Region. Nat Prod J. 22 (001), 97, 2007

25. NOUMI Z. Effects of exotic and endogenous shrubs on understory vegetation and soil nutrients in the south of Tunisia. J. Arid Land. 7, 481, 2015.

26. WEISHAAR J.L., AIKEN G.R., BERGAMASCHI B.A., FRAM M., FUJII R., MOPPER K. Evaluation of specific ultraviolet absorbance as an indicator of the chemical composition and reactivity of dissolved organic carbon. Environ. Sci. Technol. 37, 4702, 2003.

27. MATILAINEN A., GJESSING E.T., LAHTINEN T., HED L., BHATNAGAR A., SILLANPAEAE M. An overview of the methods used in the characterisation of natural organic matter (NOM) in relation to drinking water treatment. Chemosphere. 83 (11), 1431, 2011.

28. HE X.S., XI B.D., WEI Z.M., JIANG Y.H., GENG C.M., YANG Y., LIU H.L. Physicochemical and spectroscopic characteristics of dissolved organic matter extracted from municipal solid waste (MSW) and their influence on the landfill biological stability. Bioresour. Technol. 102 (3), 2322, 2011

29. LI Y.P., WANG S.R., ZHANG L., ZHAO H.C., JIAO L.X., ZHAO Y.L., HE X.S. Composition and spectroscopic characteristics of dissolved organic matter extracted from the sediment of Erhai Lake in China. J. Soils Sediments. 14 (9), 1599, 2014.

30. MINERO C., LAURI V., FALLETTI G., MAURINO V., PELIZZRTTI E., VIONE D. Spectrophotometric Characterisation of Surface Lakewater Samples: Implications for the Quantification of Nitrate and the Properties of Dissolved Organic Matter. Annali Di Chim. 97 (10), 1107, 2007.

31. GUAN S., DOU S., GUANG C., WANG G., ZHUANG $\mathrm{J}$. Isotopic characterization of sequestration and transformation of plant residue carbon in relation to soil aggregation dynamics. J Appl Ecol. 96, 18, 2015.

32. FAN C.Y., XIE X.H., YAN A.C., ZHANG J.J. Structure and $\mathrm{Cu}$ (II) Adsorption of Soil Humin. Acta Pedologica Sin. 55 (06), 1460, 2018 [In Chinese].

33. ZHANG L., SUN Q.X., PENG Y.Z., ZHAO H.C., LIU H., YOU Y., ZHANG Y.N. Components and structural 
characteristics of dissolved organic matter in the overlying water of the Beiyun River. Energy. 119921, 2021.

34. SHAHBAZ M., KUZYAKOV Y., SANAULLAH M., HEITKAMP F., ZELENEV V., KUMAR A., BLAGODATSKAYA E. Microbial decomposition of soil organic matter is mediated by quality and quantity of crop residues: Mechanisms and thresholds. Biol Fert Soils. 53 (3), 287, 2017.

35. NAGATA T. Production mechanisms of dissolved organic matter. Microb. Ecol. Oceans 121, 2000.

36. SHAHBAZ M., KUZYAKOV Y., SANAULLAH M., HEITKAMP F., ZELENEV V., KUMAR A., BLAGODATSKAYA E. Microbial decomposition of soil organic matter is mediated by quality and quantity of crop residues: Mechanisms and thresholds. Biol. 513 Fert Soils.. 53 (3), 287, 2017.

37. DUNGAIT J.A.J., HOPKINS D.W., GREGORY A.S., WHITMORE A.P. Soil organic matter turnover is governed by accessibility not recalcitrance. Glob Change Biol. 18 (6) 1781, 2012.

38. SCHMIDT M.W., TORN M.S., ABIVEN S., DITTMAR T., GUGGENBERGER G., JANSSENS I., KLEBER M., KOGEL-KNABNER I., LEHMANN J., MANNING D.A., NANNIPIERI P., RASSE D., WEINER S., TRUMBORE S. Persistence of soil organic matter as an ecosystem property. Nat. Catal. 478 (7367), 49, 2011.
39. HAN L., SUN K., JIN J., XING B. Some concepts of soil organic carbon characteristics and mineral interaction from a review of literature. Soil Biol. Biochem. 94, 107, 2016.

40. XU Z.J., LIU G.S., LIU W.P. Environmental characteristics and behavior of dissolved organic matter in soil. Environ Chem Lett, 22 (5), 427, 2003.

41. LEI D., GUO B., LIU Z.P., SHANG G. Land-use conversion and changing soil carbon stocks in China's 'Grain-for-Green' Program: a synthesis. Glob. Change Biology. 20 (11), 3544, 2015.

42. HUANG J.F. Organic acids secreted by plant roots and their functions. Modern Agric. Sci. Technol. 20, 323, 2008 [In Chinese].

43. ZHANG H., CHU L. Plant community structure, soil properties and microbial characteristics in revegetated quarries. Ecol. Eng. 37, 1104, 2011.

44. ROUSK J., BAATH E., BROOKES P.C., LAUBER C., LOZUPONE C., CAPORASO J.G., KNIGHT R., FIERER $\mathrm{N}$. Soil bacterial and fungal communities across a $\mathrm{pH}$ gradient in an arable soil. The ISME J. 4 (10), 1340, 2010.

45. LIU W., WEI J., CHENG J., LI W. Profile distribution of soil inorganic carbon along a chronosequence of grassland restoration on a 22-year scale in the Chinese Loess Plateau. Catena (Amst). 121 (7), 321, 2014. 